Regnault, Frost, Fairbairn, Tate, and others have shown that the rate of expansion of superheated steam is almost identical with that of air and other permanent gas, if calculated not too close to the temperature of maximum saturation. In passing steam through pipes heated by the hot gases from the furnace, the effect is not much, if any, better than using a trap to separate the water of condensation.

It is obvious that, for steam to pass from a boiler into a superheater, the latter can only be at the same pressure as the boiler, or somewhat lower, and the gasification in transit is not attended by increased density nor exalted tension; hence the failure of ordinary superheaters.

Practical engineers-makers of high-pressure engines for the trade-discovered long since that compression of steam at the end of each stroke, or steam cushioning, notwithstanding certain theoretical disadvantages, yielded an average efficiency greatly in excess of free discharge of steam from the cylinder. In this case superheating, of course, occurs, by compression, under circumstances insuring exalted tension; hence the economy. Hook's law, "Ut tensio sic vis," cannot be translated into "Ut calor sic vis."

The Laboratory, 3 Church Street, Westminster, S.W., February 23.

\section{Poincaré's "Thermodynamics."}

I FEAR M. Poincaré has not read my review of his book with sufficient attention. Otherwise he could hardly have written the letter printed in your last number.

The chief objections I made, taken in the reverse order of their importance, were

I. The work is far too much a mere display of mathematical skill. It soars above such trifles as historical details, while overlooking in great measure the experimental bases of the theory; and it leaves absolutely unnoticed some of the most important branches of the subject.

[Thus, for instance, Sadi Carnot gets far less than his due, Rankine is not alluded to, and neither Thermodynamic Motivity nor the Dissipation of Energy is even mentioned !]

2. It gives an altogether imperfect notion of the true foundation for the reckoning of absolute temperature.

3. It completely ignores the real (i.e. the statistical) basis of the Second Law of Thermodynamics.

If these are what M. Poincaré alludes to as "reproches généraux, contre lesquels ma préface proteste suffisamment," I can only express genuine amazement that a Preface should be capable of having such powers, and envy the man who is able to write one.

As to smaller matters :-I did not attack M. Poincaré's printer, I virtually said he was excusable under the circumstances. And as to the quite subsidiary question which $M$. Poincaré seems to think I regard as the most important, I have only to say that I could scarcely be expected to know that the words " on n'a pu jusqu'ici constater l"existence des forces electromotrices, \&c.," imply, as M. Poincaré now virtually interprets them, "One has not yet been able to assign the orizin of the electromotive forces, \&c."

P. G. T.

$4 / 3 / 92$

\section{The Function of a University.}

YET one more definition-it is no part of the business of a University to teach, says Prof. Fitzgerald in NATURE of February 25 (p. 392). We have now the following definitions of the function of a University :-

I. It should be a mere examining body, e.g. the London University.

2. It is a place for the cultivation of athletics, good breeding, and gentlemanly behaviour.

3. At the University there should be taught classics, mathematics, and pure science.

4. The Professors of the University should teach useful subjects like mechanical and electrical engineering, medicine, \&c., as at Cambridge.

5. The true function of the University is the teaching of useless learning.

6. It is no part of the business of a University to teach.

Truly, a wide choice of definitions, and seeing that the teaching of applied science which has been developed "at schools, technical colleges, by patent-mongers and the trade," No. I 167 , vor. 45] aided " by a lot of savages," has been recently appropriated by the Universities, I have no doubt, when these degraded mortals have similarly worked out a system of teaching applied literature, that a seventh definition of the function of a University will be added later on, viz. :-

7. At the University, modern languages and literature are studied in such a way as to be of the greatest value to the nation at large.

As Prof. Fitzgerald relegates the teaching of things useful to the class of pariahs mentioned above, perhaps be will tell us whether he raises the study of mechanical and electrical engineering to the lofty position of uselessness, or whether he utterly condemns the appeal that is now being widely mademade even to technical teachers - for aid in the establishment of engineering laboratories at a University which bas recently thought that the best place to obtain an assistant was a London technical college.

He thinks that students, "if they are so ill prepared that they have not acquirer the art of learning, should go to a College, ..." and not to the University. I presume, then, that they ought to go, for example, to the Colleges of Trinity or St. John's, but not to Cambridge; or to the Colleges of Balliol or Christ's, but on no account to Oxford. Perhaps this somewhat conflicting advice is the result of Prof. Fitzgerald's studying literature "for its own sake," as contrasted with studying language for the sense it conveys. Examples were recently given in a leader in one of the daily papers illustrating that the public utterances of some of the most prominent advocates of the compulsory teaching of Greek conclusively proved that it was not to improve their English that they had studied the classics.

In the same lucid way Prof. Fitzgerald adds: "The Bible produced very little effect until it was read in translations; and the danger of a pagan revival, if ancient literature were studied without the obstruction of difficult languages, is the best reason for insisting on those languages in a Christian University." Surely a man of his wide intellectual power cannot mean that the general reading of the Bible, which became possible after it was translated into modern languages, is to be deplored. But neither, on the other hand, can he mean that the incalculable benefit, that has resulted from the translation of the Bible into the vulgar tongue is an argument for the suppression of free translation. On whichever horn of his own dilemma he decides to pose himself, I, at any rate, have no sympathy with the Roman Catholic dogma that good comes from making the knowledge of the truth difficult of attainment by the world at large.

He chides me with forgetting the debt electrical science owes to those who studied it while useless. Does the statement that one Volt sends one Ampere-that is, one Coulcmb per secondthrough one $O \mathrm{hm}$ look as if the practical electrical engineer had forgotten the labours of Volta, of Ampere, of Coulomb, and of Ohm? Indeed, is not Prof. Fitzgerald himself forgetting the deep debt of gratitude the theoretical study of electricity owes to its practical applications? The late Prof. Fleeming Jenkin, a Professor at a University bear in mind, wrote in $1873:-$ " In England at the present time it may almost be said that there are two sciences of electricity-one that is taught in ordinary textbooks, and the other a sort of floating science known more or less perfectly to practical electricians. . . . A student might have mastered Delarive's large and valuable treatise, and yet feel as if in an unknown country and listening to an unknown tongue in the company of practical men. It is also not a little curious that the science known to the practical men was, so to speak, far more scientific than the science of the text-books."

While there are University Professors like Thomson, Hertz, and Fitzgerald, what matters it whether we call them the teachers or ourselves the learners? When the work they are now carrying on may be of incalculable service to the practical man in the future, of what avail is it to discuss whether it is today useful or useless? For the labours of such men I have too profound a respect and admiration to "sneer" at what I hold to be the true function of the University.

But equally worthy of respect do I think is the teacher in a school of engineering - that is, one who aims at presenting useful knowledge, and the methods for extending it, in such a form as to be most easily grasped by those who intend to devote their lives to engineering.

My friend Prof. Fitzgerald and $I$ are at any rate wholly in accord on one important point urged in my recent inaugural address, viz. that it is the special function of the technical school to teach useful knowledge.

W. E. Ayrton. 